\title{
System Monitoring Traffic Density Application based on Neural Network Algorithms
}

\author{
Ari Wijayanti*, Nur Adi Siswandari, Haniah Mahmudah, Okkie Puspitorini, Chusnul Chotimah \\ Politeknik Elektronika Negeri Surabaya \\ Kampus PENS, Jalan Raya ITS Sukolilo, Surabaya 60111, Indonesia \\ *Corresponding author's email: ariw [AT] pens.ac.id
}

\begin{abstract}
The increase in vehicle traffic density in a city correlates with increasing private vehicle usage. This problem is caused by the lack of public transport services. In other side, the volume of private vehicles increases the traffic density and cause problems are jammed in rush hour traffic. Use of the application can help road users to know the traffic conditions at real time. The research has developed a mobile application of information about traffic condition. This application is created using Android software programming, Android Development Tool (ADT) integrated with Google Maps so it can display information points from jammed location. The information presented in the form of the location name, location coordinates (latitude, longitude), the average vehicle speed (Km / h) which pass through the area and the traffic status in the form of a solid, jammed or smoothly. The data was predicted by Backpropagation Neural Network. The performance has seen on the size of MSE (Mean Square Error). The result is the smallest MSE are 8,91x10-24, it means the chosen method has a predictability that is very close to the actual conditions of traffic situation.
\end{abstract}

Keywords—- Android Development Tools, Backpropagation neural network, MSE

\section{INTRODUCTION}

At last decade, with the increasing population density in metropolis city impact on congestion, accidents and traffic violations. Therefore, It takes a transportation information system to solve various traffic problems. [1] There have been many applications to support the problems solving related to traffic jams to avoid traffic location or traffic areas. The accuracy is a problem for the provision of traffic congestion data, where the information is still relying on the user to feed congestion information.

There are several studies that have been done previously about application development such as Waze, dan Google Maps [2]. The distinguish idea comes from the application of campus assistant on android platform where are illustrated for Florida Atlantic University - Boca Raton Campus [3]. This apps serves the detail maps inside the campus building for new student a visitor which are not support by Google maps. The similar situation appears in developing country roads such as Surabaya Indonesia. The most problems are crowded situation early morning and in the end of the noon when the public mobility flows from business district area to resident area. The government serves traffic information using static web [4]. Base on the main problems in urban area traffic condition, the regulations are followed to solve these problems [5].

The paper is organized as follows. In section 2 is the parameter of traffic information design such as stage of processing in server and client. Section 3 present the backpropagation neural network algorithm to predic the traffic condition in future. The next section gives simulation result and performance analysis achieved and finally, section 5 concludes the paper result.

\section{PARAMETER DESIGN}

The application is built using the Android programming softwareAndroid Development Tool (ADT) This application is integrated with Google Maps so that it can display information points which location is jammed, solid or smooth traffic in Surabaya. The information presented in the form of the location name, location coordinates (latitude, longitude), the average vehicle speed $(\mathrm{Km} / \mathrm{h})$ which pass through the area and the traffic status in the form of a solid, jammed or smoothly. That information is stored in a MySQL database that is connected with the application, so that at every hour application will update the information based on the database. In this research, data location and the average speed of vehicle is obtained from the Department of Transportation Surabaya, where every day traffic conditions are monitored. Overall system block diagram shown in Figure 1. 


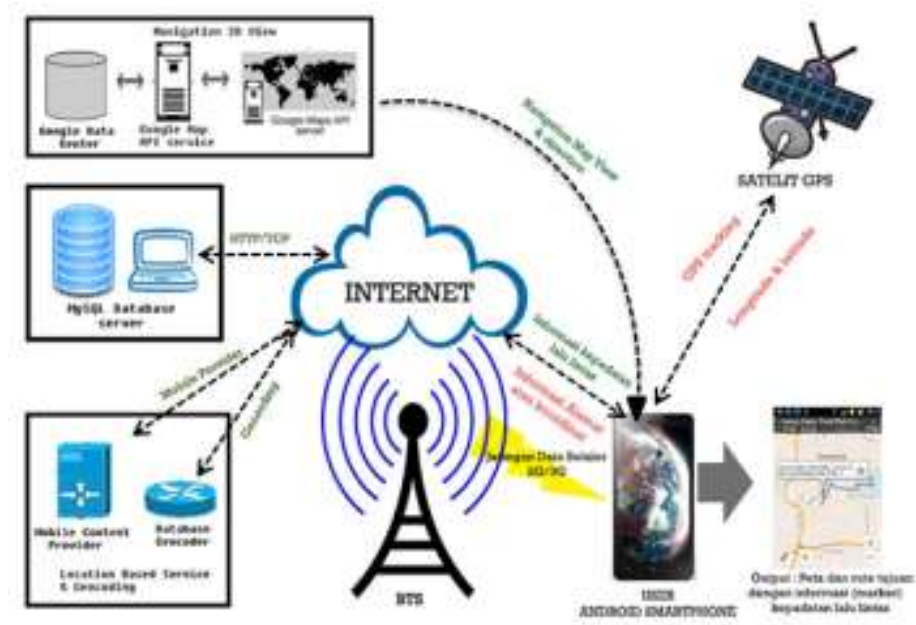

Figure 1. Blok diagram all system

Figure 1 arranged stages of processing system into two parts, the server and client. Details present in Figure 2 as follows:

\section{Server}

On the server side, there are several stages of processing, among others:

a. Data collection

b. The data processing method of prediction with Backpropagation Neural Network and for the accuracy of the data by the method of Mean Square Error (MSE)

c. manufacture Database

d. Making the Web as a server

2. Client

On the client side, the work done is the creation of applications based on Android which is used in the application on the user's smartphone. Several stages of making the application are:

a. Configuring Google Map API Key

b. Displaying Google Map

c. Displays the user's position using application

d. Featuring dense traffic information

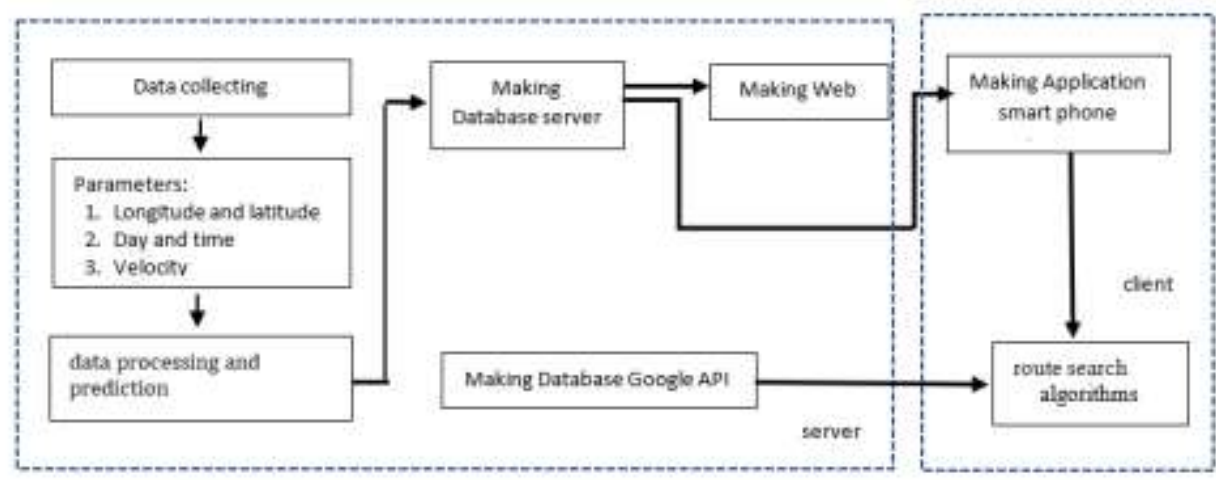

Figure 2.Blok diagram of processing system

At the end of the research, an application to navigate congestion traffic information based on Android will be presented.

\section{BACKPROPAGATION NEURAL NETWORK ALGORITHM}

This section describe the data processing for backpropagation neural network algorithm take two steps as follows 


\section{A. Data Collection}

At this stage of data collection, where data is obtained based on statistical data the average density of traffic at the junction of the Department of Transportation Surabaya Surabaya. Data obtained from 20 CCTV cameras were installed at a crossroads. The data show the number of vehicles crossing the area. Data location of a camera mounted at the intersection are presented in Table 2. Base on the captured data from the crossroads in front of the camera, the average of the vehicle numbers are change daily in every minute at each junction and will be used as a reference number for category of traffic conditions. The standardization of traffic category such as standstill, solid or smooth, base on the Regulation of the Minister of Transportation No. KM 14, 2006 Chapter III, Article 7 Planning Traffic on the level of service on roads, as shown in Table 1.

Table 1. Average Density Traffic Parameter [5]

\begin{tabular}{|l|c|}
\hline \multicolumn{1}{|c|}{ Parameter } & $\begin{array}{c}\text { Kecepatan } \\
\text { Rata-rata }(\mathrm{Km} / \mathbf{h})\end{array}$ \\
\hline Traffic jams & $\leq 25 \mathrm{Km} / \mathrm{h}$ \\
\hline Congested traffic & $30 \mathrm{Km} / \mathrm{h} \mathrm{s} / \mathrm{d} 25 \mathrm{Km} / \mathrm{h}$ \\
\hline Smooth traffic & $\geq 30 \mathrm{Km} / \mathrm{h}$ \\
\hline
\end{tabular}

Table 2. Data Layout Camera Mounted at the crossroads [4]

\begin{tabular}{|c|c|c|c|c|}
\hline Camera & Location & Latitude & Longitude & Address \\
\hline 1 & Al Falah & -7.294637 & 112.73926 & $\begin{array}{l}\text { Tm } \\
\text { Mayangkara }\end{array}$ \\
\hline 2 & Ciliwung & -7.29234 & 112.73708 & J1 Ciliwung \\
\hline 3 & Dr.Sutomo & -7.284583 & 112.73329 & $\begin{array}{l}\text { J1. Raya Dr } \\
\text { Soetomo }\end{array}$ \\
\hline 4 & $\begin{array}{l}\text { Sahid } \\
\text { Hanamasa }\end{array}$ & -7.26634 & 112.75114 & J1 Pemuda \\
\hline 5 & $\begin{array}{l}\text { Samsat } \\
\text { kertajaya }\end{array}$ & -7.279433 & 112.7622 & \begin{tabular}{|l|} 
J1 Manyar \\
Kertoajo
\end{tabular} \\
\hline 6 & Siola & -7.255784 & 112.73698 & $\begin{array}{l}\text { J1 Genteng } \\
\text { Kali }\end{array}$ \\
\hline 7 & Mustopo & -7.265713 & 112.75741 & $\begin{array}{l}\text { J1 Prof Dr } \\
\text { Mustopo }\end{array}$ \\
\hline 8 & $\begin{array}{l}\text { Ngagel Jaya- } \\
\text { Utara }\end{array}$ & -7.286847 & 112.75587 & J1 Kalibokor \\
\hline 9 & $\begin{array}{l}\text { Kedung } \\
\text { Doro }\end{array}$ & -7.266077 & 112.73006 & \begin{tabular}{|l|} 
J1 Kedung \\
Doro
\end{tabular} \\
\hline 10 & $\begin{array}{l}\text { Embong } \\
\text { Malang }\end{array}$ & -7.258396 & 112.73314 & $\begin{array}{l}\text { J1 Embong } \\
\text { Malang }\end{array}$ \\
\hline 11 & $\begin{array}{l}\text { Jembatan } \\
\text { Rolak }\end{array}$ & -7.307032 & 112.72061 & $\begin{array}{l}\text { J1 Gunung } \\
\text { Sari }\end{array}$ \\
\hline 12 & $\begin{array}{l}\text { Mayjen } \\
\text { Sungkono }\end{array}$ & -7.29059 & 112.71432 & $\begin{array}{l}\text { J1 Mayjen } \\
\text { Sungkono }\end{array}$ \\
\hline 13 & Margorejo & -7.316253 & 112.73402 & $\begin{array}{l}\text { J1 Raya } \\
\text { Margorejo }\end{array}$ \\
\hline 14 & Dinoyo & -7.279584 & 112.74394 & J1 Dinoyo \\
\hline 15 & $\begin{array}{l}\text { Jagalan- } \\
\text { Peneleh }\end{array}$ & -7.247861 & 112.74238 & J1 Peneleh \\
\hline 16 & Praban & -7.255973 & 112.7342 & J1 Praban \\
\hline 17 & Tembaan & -7.246942 & 112.73682 & J1 Tembaan \\
\hline 18 & Kutai & -7.294353 & 112.73186 & J1 Kutai \\
\hline 19 & Kertajaya & -7.278376 & 112.75582 & J1 Kertajaya \\
\hline 20 & Wapo & -7.270664 & 112.76066 & $\begin{array}{l}\text { J1 Karang } \\
\text { Menjangan }\end{array}$ \\
\hline
\end{tabular}

\section{B. Data Prediction using Backpropagation Neural Network}

Prediction data is done using Backpropagation Neural Network consists of architectural design, design of input-output data and the process of training and testing process as describes below 
i. The design of System Architecture

System architecture used in the Neural Network is made up of three layers, inpu tlayer, hidden layer and output layer. Figure 3 shows Architecture of weekly sessions contain 24 input layer, one hidden layer with number of nodes are 20 and number of output layer are 7. In Figure 4 shows Architecture of daily sessions contain 24 input layer, one hidden layer with number of nodes are 20 and one output layer.

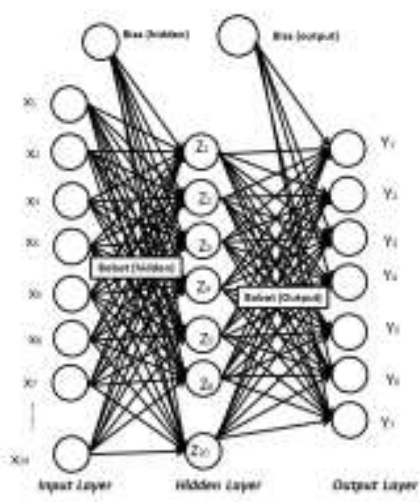

Figure 3. Neural Network Algorithm architecture weekly sessions $(24,20,7)$

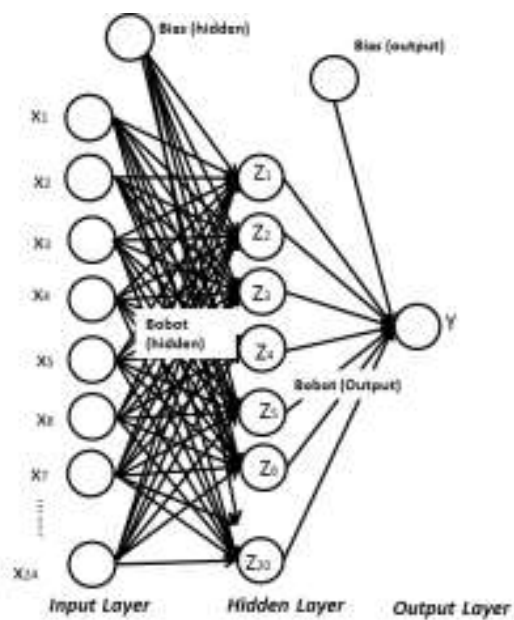

Figure 4. Neural Network Algorithm architecture dayly sessions $(24,20,1)$

There are two architecture scenarios for this research, weekly sessions and daily sessions. For second session the architecture of the input layer and output layer are different, the similarity happend on the hidden layer.

The units for input layer is a lag value Xt of target data, while in the hidden layer is a similar value from the target data $\mathrm{Zt}$ lag. When the output layer in scenario 1 (weekly sessions) unit is a lag Yt value and the target data in the second scenario is a unit of $\mathrm{Yt}$ value too.

The flow of information systems in Neural Network algorithm is to predict traffic density data. First data set come from the inclusion of the amount of data that will be in training. Data were obtained from data collection along 4 months, i.e. data for March, April, May and June 2015. Those data become initial input and function for the target data as use as a parameter for the computation process in neural Network Algorithm. Another parameter used is the learning rate $(\alpha)$, tolerance error $(\theta)$ and the number of units in the hidden layer.

\section{ii. $\quad$ Training Process}

In the training process, there are several other parameters that are in addition to input the data traffic density and the target which is the reference for the training process, the parameter is the learning rate $(\alpha)$, tolerance error $(\theta)$, the number of nodes in the hidden layer and the activation function used. These parameters more details can be seen in Table 3 . 
Table 3. Training process parameters on method of Backpropagation Neural Network

\begin{tabular}{|l|l|}
\hline \multicolumn{1}{|c|}{ Parameter } & \multicolumn{1}{|c|}{ Keterangan } \\
\hline Neural Network Method & Backpropagation \\
\hline $\begin{array}{l}\text { The number of nodes in the } \\
\text { hidden layer }\end{array}$ & 1 layer, 20 nodes \\
\hline $\begin{array}{l}\text { Activation function in the } \\
\text { hidden layer }\end{array}$ & Sigmoid Bipolar \\
\hline Performance function & Mean Square Error (MSE) \\
\hline Learning rate & 0.0001 \\
\hline Maximum Iteration & 10000 \\
\hline
\end{tabular}

In the training process, the input data will be normalized so that the output data will be generated to describe the pattern of data as before. Afterwards, the training process then generate the values of the most optimal weight neural network algorithm stored for testing process.

\section{iii. Testing Process}

In the process of testing the input or the input variable is a data training results and data testing. In this process the data is normalized at denormalization training process so that data values can be restored with post std function in matlab.

In this process will result in the output of the forecast data in accordance with the architecture of each scenario. Wherein the first scenario i.e. weekly sessions, will be produced 7 series output data is the data for one week (Monday Sunday).

\section{Making Database server}

In making this database, data entered as traffic density data is data predicted results by the method of Backpropagation Neural Network has been done. making this database may take a few variables needed for the data from this database can be well informed on the user.

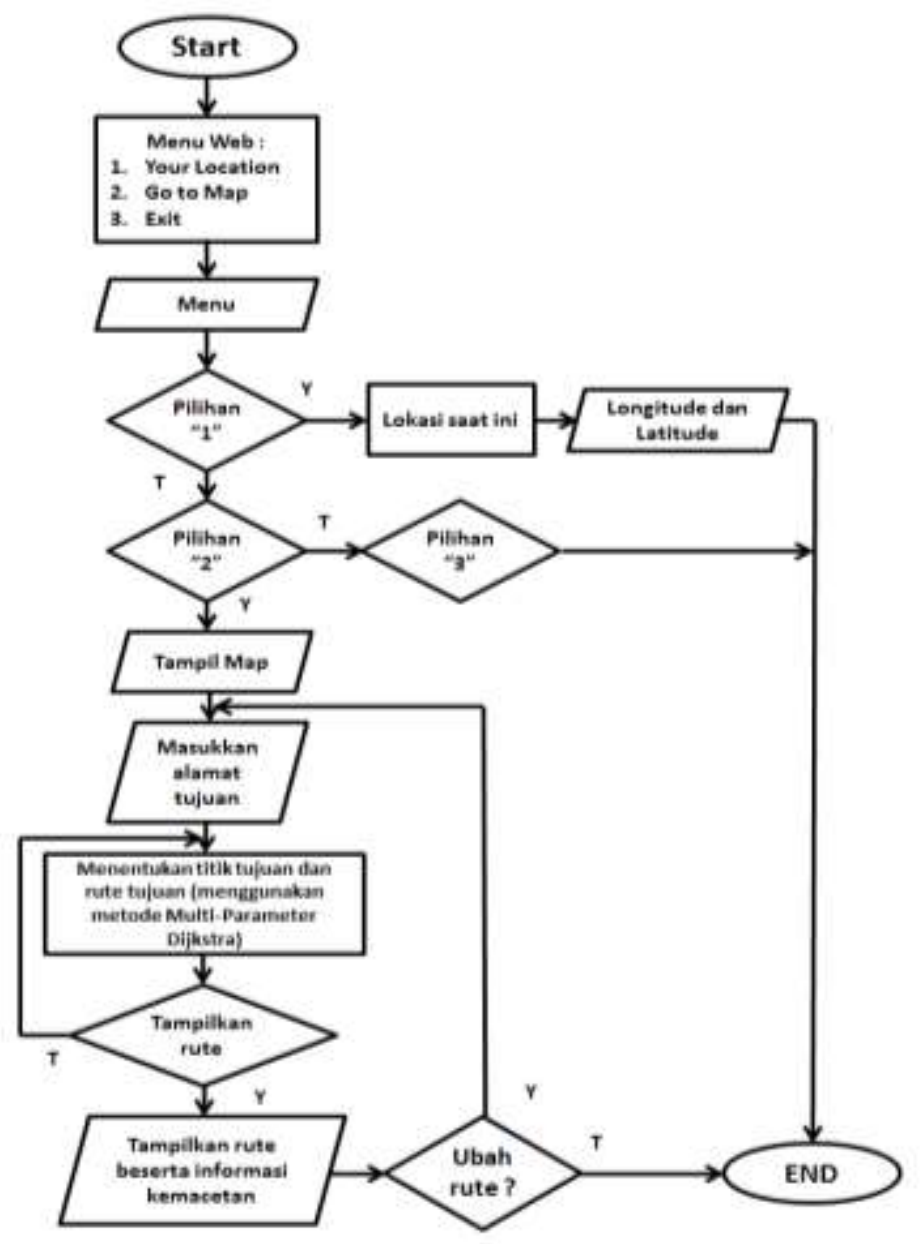

Figure 5. Flowchart application system 


\section{Preparation System Applications "Traffic Monitor" based on Android}

Making the application system "Traffic Monitor" is made with Android Java language, which is that this application can be used by users in the handset (smartphone) that uses the Android OS. This application will show where the current user position on the map of Google Maps that is already integrated with the application. Additionally, it will be displayed predictive traffic data in Surabaya at points indicated location dense, smooth jams or traffic, which is where the information data is obtained from a database that has been created. System flowchart applications created can be seen in Figure 5. Whereas display applications like Figure 6.

\section{SIMULATION RESULTS AND PERFORMANCE ANALYSIS}

After the process of designing and manufacturing of complete systems, is the process of testing the system to obtain data that will be analyzed. System testing and parameter is passed with the following provisions:

\section{A. Backpropagation Method}

i. Scenario 1: Weekly Session

From the results of the training process can be seen the difference the training process at one location to location 20. The results of training can be seen in Table 4. From the acquisition of the training results obtained how many iterations occur, performance and time computing network system. After the training process, then the data in testing to obtain the desired prediction data, namely in Table 5

Table 4. Results of the training process on a weekly session

\begin{tabular}{|l|c|c|c|}
\hline \multirow{2}{*}{ Location } & \multicolumn{3}{|c|}{ Result of training process on a weekly session } \\
\cline { 2 - 4 } & $\begin{array}{c}\text { Iterasi } \\
\text { (Epoch) }\end{array}$ & $\begin{array}{c}\text { Performance } \\
\text { (MSE) }\end{array}$ & $\begin{array}{c}\text { Computation } \\
\text { time }\end{array}$ \\
\hline C1 & 11 & $1,73 \times 10^{-22}$ & 9 second \\
\hline C2 & 13 & $1.28 \times 10^{-22}$ & 22 second \\
\hline C3 & 10 & $1,73 \times 10^{-14}$ & 13 second \\
\hline C4 & 20 & $2,13 \times 10^{-13}$ & 20 second \\
\hline C5 & 12 & $1,98 \times 10^{-14}$ & 24 second \\
\hline C6 & 13 & $3,24 \times 10^{-16}$ & 19 second \\
\hline C7 & 21 & $2,05 \times 10^{-7}$ & 56 second \\
\hline C8 & 14 & $2,73 \times 10^{-15}$ & 20 second \\
\hline C9 & 10 & $1,34 \times 10^{-14}$ & 12 second \\
\hline C10 & 11 & $1,79 \times 10^{-18}$ & 17 second \\
\hline C11 & 11 & $3,71 \times 10^{-14}$ & 30 second \\
\hline C12 & 26 & $2,26 \times 10^{-23}$ & 55 second \\
\hline C13 & 15 & $3,32 \times 10^{-13}$ & 42 second \\
\hline C14 & 12 & $4,20 \times 10^{-15}$ & 36 second \\
\hline C15 & 11 & $1,73 \times 10^{-14}$ & 12 second \\
\hline C16 & 11 & $5,05 \times 10^{-16}$ & 21 second \\
\hline C17 & 10 & $2,82 \times 10^{-17}$ & 19 second \\
\hline C18 & 13 & $4,08 \times 10^{-15}$ & 25 second \\
\hline C19 & 11 & $1,73 \times 10^{-16}$ & 20 second \\
\hline C20 & 10 & $5,00 \times 10^{-14}$ & 19 second \\
\hline
\end{tabular}


Table 5. Results of the testing process (data prediction)

\begin{tabular}{|c|c|c|c|c|c|c|c|}
\hline \multirow[b]{2}{*}{ Jam } & \multicolumn{7}{|c|}{ Hasil Prediksi - Kecepatan rata-rata $(\mathrm{Km} / \mathrm{h})$} \\
\hline & \begin{tabular}{|l}
28 Juni \\
2015
\end{tabular} & $\begin{array}{l}29 \text { Juni } \\
2015\end{array}$ & \begin{tabular}{|l}
$\begin{array}{l}\text { 30 Juni } \\
2015\end{array}$ \\
\end{tabular} & $\begin{array}{l}1 \text { juli } \\
2015\end{array}$ & $\begin{array}{l}2 \text { Juli } \\
2015\end{array}$ & $\begin{array}{l}3 \text { Juli } \\
2015\end{array}$ & $\begin{array}{l}\text { 4 Juli } \\
2015\end{array}$ \\
\hline 0 & 52 & 57 & 50 & 50 & 50 & 45 & 52 \\
\hline 1 & 36.3569 & 38.4146 & 37.7377 & 33.577 & 38.939 & 34.166 & 38.973 \\
\hline 2 & 52 & 57 & 60 & 57 & 55 & 55 & 47 \\
\hline 3 & 55 & 46 & 57 & 50 & 55 & 45 & 52 \\
\hline 4 & 50 & 54 & 55 & 55 & 55 & 55 & 50 \\
\hline 5 & 49 & 44 & 55 & 54 & 50 & 50 & 47 \\
\hline 6 & 38.264 & 40.6507 & 29.2239 & 36.693 & 32.158 & 37.205 & 38.81 \\
\hline 7 & 43.4523 & 43.0799 & 26.5376 & 34.344 & 28.559 & 29.11 & 31.441 \\
\hline$\overline{8}$ & 35 & 34 & 27 & 33 & 30 & 29 & 35 \\
\hline 9 & 34 & 35 & 32 & 31 & 31 & 29 & 30 \\
\hline 10 & 30 & 32 & 35 & 31 & 35 & 30 & 31 \\
\hline 11 & 37 & 32 & 35 & 32 & 35 & 29 & 31 \\
\hline 12 & 37.006 & 38.4746 & 35.4804 & 39.786 & 34.8 & 40.14 & 35.983 \\
\hline 13 & 30 & 34 & 32 & 34 & 31 & 31 & 31 \\
\hline 14 & 31.3206 & 32.1237 & 33.4921 & 31.618 & 31.183 & 28.153 & 27.826 \\
\hline 15 & 37.8593 & 22.8255 & 29.1276 & 24.532 & 26.84 & 23.813 & 25.567 \\
\hline 16 & 35 & 25 & 34 & 30 & 30 & 29 & 27 \\
\hline 17 & 29.7531 & 25.5087 & 28.7124 & 27.481 & 26.91 & 28.175 & 26.225 \\
\hline 18 & 33.1069 & 41.3528 & 30.4486 & 28.969 & 31.557 & 27.421 & 29.76 \\
\hline 19 & 35 & 43 & 35 & 34 & 35 & 31 & 29 \\
\hline 20 & 36 & 43 & 35 & 35 & 35 & 33 & 35 \\
\hline 21 & 30 & 47 & 40 & 35 & 35 & 37 & 35 \\
\hline 22 & 40 & 47 & 47 & 48 & 45 & 45 & 45 \\
\hline 23 & 45 & 50 & 50 & 50 & 45 & 45 & 45 \\
\hline
\end{tabular}

ii. Scenario 2: Dayly Session

Table 6. Results of the training process on a daily session

\begin{tabular}{|l|c|c|l|}
\hline \multirow{2}{*}{ Location } & \multicolumn{3}{|c|}{ Result of training process on a dayly session } \\
\cline { 2 - 4 } & $\begin{array}{c}\text { Iterasi } \\
\text { (Epoch) }\end{array}$ & $\begin{array}{c}\text { Performance } \\
\text { (MSE) }\end{array}$ & $\begin{array}{c}\text { Waktu } \\
\text { komputasi }\end{array}$ \\
\hline C1 & 4 & $1,12 \times 10^{-20}$ & 5 second \\
\hline C2 & 4 & $4,28 \times 10^{-15}$ & 5 second \\
\hline C3 & 4 & $4,23 \times 10^{-15}$ & 5 second \\
\hline C4 & 4 & $4,96 \times 10^{-18}$ & 5 second \\
\hline C5 & 4 & $8,36 \times 10^{-16}$ & 5 second \\
\hline C6 & 4 & $4,41 \times 10^{-15}$ & 5 second \\
\hline C7 & 4 & $1,53 \times 10^{-17}$ & 5 second \\
\hline C8 & 4 & $2,23 \times 10^{-20}$ & 5 second \\
\hline C9 & 4 & $1,34 \times 10^{-23}$ & 5 second \\
\hline C10 & 5 & $1,75 \times 10^{-20}$ & 6 second \\
\hline C11 & 4 & $2,68 \times 10^{-15}$ & 5 second \\
\hline C12 & 4 & $1,65 \times 10^{-12}$ & 5 second \\
\hline C13 & 4 & $5,19 \times 10^{-17}$ & 5 second \\
\hline C14 & 4 & $2,39 \times 10^{-16}$ & 5 second \\
\hline C15 & 15 & $1,46 \times 10^{-15}$ & 25 second \\
\hline C16 & 5 & $5,36 \times 10^{-23}$ & 6 second \\
\hline C17 & 4 & $6,69 \times 10^{-17}$ & 5 second \\
\hline C18 & 5 & $9,48 \times 10^{-19}$ & 5 second \\
\hline C19 & 4 & $3,60 \times 10^{-16}$ & 5 second \\
\hline C20 & 5 & $8,91 \times 10^{-24}$ & 6 second \\
\hline
\end{tabular}

From the test results of data prediction system using Backpropagation Neural Network, carried out on two scenarios, namely Scenario 1: weekly sessions and scenario 2: daily sessions.

In scenario 1, it can be seen that the most excellent performance dianatra 20 location point is at the location of the $\mathrm{C} 12$ with the value of MSE of 2,1x10-23 with many iterations as many as 26 epochs and computation time for 55 second. In the training process, the number of iteration / epoch has no effect on long computation time, the cause of many iterations since the system is still not able to find the weights and bias values corresponding to the target data and the value of the error (MSE) is small, so the iteration will continue to run until it finds The smallest error and in accordance with the target data. Once the training process is done, then the process of testing, where the input or the input is the result of the training process within the extension * .mat. In addition, testing of data is the data that will be simulated to produce the output of the data input. Data from this testing process which is the final output data (prediction data) for 1 week (7 days) as shown in Table 5. From the results of these predictions, compared with actual 
data, ie data on the predicted date, on which they are carried out on June 28, 2015 to July 4, 2015. This test was conducted to test the correctness and performance of the back propagation method.

Similar to the first scenario, the scenario 2: Daily sessions also done the same thing. But the difference is the target data and output. Data output on a daily sessions just one row of data that represents prediction data one day. From the training results in Table 6, the most excellent performance with the smallest MSE value is $8,91 \times 10-24$ in location $\mathrm{C} 20$.

iii. Testing and Analysis Comparative Testing Data Full (24 hours) and not full (not 24 hours)

In this test done testing and comparison of data is not full (data not 24 hours) in the testing process. This test aims to get the full 24-hour prediction data, or is unable to predict the data with the data testing that is not full. Testing the data used are full of data ( 24 hours), the data $3 / 4,1 / 21 / 4$ data and data from the full data ( 24 hours). In Table 7 are shown the data from the prediction of each data testing.

Table 7. Results of prediction data from the data testing different

\begin{tabular}{|c|c|c|c|c|}
\hline \multirow[t]{2}{*}{ Time } & \multicolumn{4}{|c|}{ Result of data prediction $(\mathrm{Km} / \mathrm{h})$} \\
\hline & $\begin{array}{l}\text { Data } \\
\text { testing } \\
\text { Full }\end{array}$ & $\begin{array}{l}\text { Data } \\
\text { testing : } 3 / 4 \\
\text { data }\end{array}$ & $\begin{array}{l}\text { Data } \\
\text { testing : 1/2 } \\
\text { data }\end{array}$ & $\begin{array}{l}\text { Data } \\
\text { testing : 1/4 } \\
\text { data }\end{array}$ \\
\hline 0 & 48 & 47.8658 & 48.0006 & 48.4146 \\
\hline 1 & 48 & 47.8794 & 48.0014 & 48.1308 \\
\hline 2 & 48.354 & 49.4311 & 48.0012 & 47.8449 \\
\hline 3 & 48.1093 & 50.2122 & 48.0024 & 47.9933 \\
\hline 4 & 45 & 44.9465 & 45.0024 & 45.2755 \\
\hline 5 & 45 & 45.0515 & 45.0004 & 45.0021 \\
\hline 6 & 38 & 38.0178 & 38.544 & 37.9622 \\
\hline 7 & 32.7882 & 35.0207 & 35.0005 & 33.4035 \\
\hline 8 & 33 & 32.9872 & 32.3941 & 33.1833 \\
\hline 9 & 34.9221 & 32.9674 & 33.0004 & 33.8175 \\
\hline 10 & 32.9527 & 32.977 & 34.3276 & 33.7179 \\
\hline 11 & 33.6034 & 31.7343 & 32.9248 & 30.5637 \\
\hline 12 & 30 & 30.9846 & 30.0012 & 30.9016 \\
\hline 13 & 30 & 29.9537 & 30.9402 & 30.8252 \\
\hline 14 & 30 & 29.969 & 30.0007 & 30.8723 \\
\hline 15 & 30 & 29.9276 & 30.0014 & 30.8461 \\
\hline 16 & 34.6902 & 33.9727 & 34.0007 & 32.0742 \\
\hline 17 & 35 & 35.0105 & 32.8561 & 34.8377 \\
\hline 18 & 43 & 43.0194 & 42.9999 & 43.0654 \\
\hline 19 & 40.1821 & 43.014 & 42.9996 & 42.986 \\
\hline 20 & 42 & 42.0049 & 42 & 41.0885 \\
\hline 21 & 45 & 45.826 & 46.3027 & 44.9866 \\
\hline 22 & 45 & 45.0348 & 45.0012 & 43.6507 \\
\hline 23 & 50 & 47.8125 & 51.1181 & 49.8368 \\
\hline
\end{tabular}

B. Result of Aplication

Results display on the traffic menu folder of the application is made is shown in Figure 6.
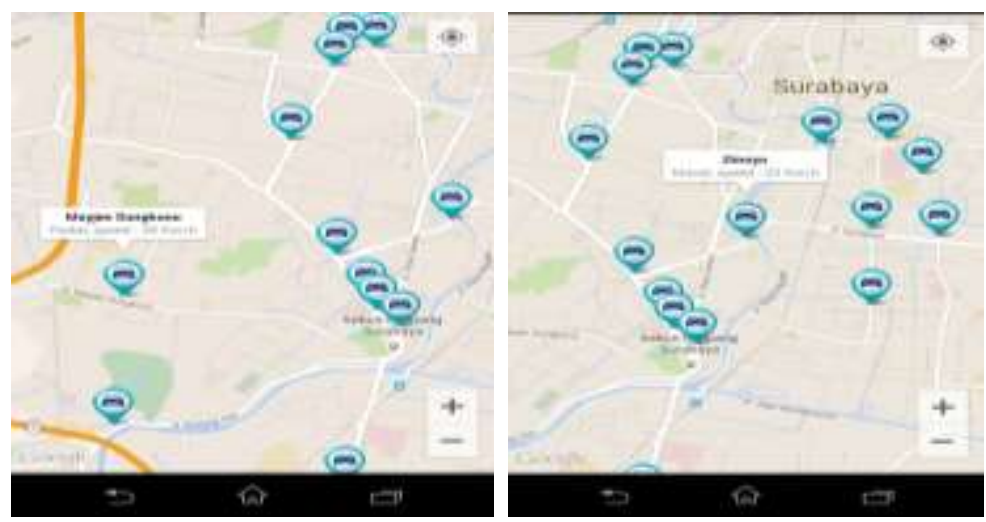

Figure 6. Display location point with traffic information 


\section{The results of data access information of the application based on data from the database}

Results of information access data from a database that Traffic Monitor application can successfully retrieve data from the database as user access times that are using the application. Results of data access is done at 20 locations at 07.00 and 12:00. In Table 8 and Table 9 takes some sample results on the data information access.

Table 8. Results of the data access information from the database at 07.00

\begin{tabular}{|c|c|c|c|}
\hline Location & Display on Aplication & $\begin{array}{c}\text { Data in } \\
\text { Database }\end{array}$ & Description \\
\hline $\mathrm{C} 1$ & 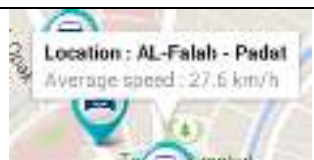 & $27,6 \mathrm{Km} / \mathrm{h}$ & $\begin{array}{c}\text { Successful } \\
\text { data retrieval }\end{array}$ \\
\hline C2 & 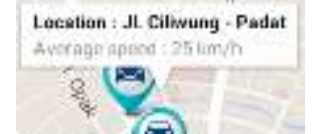 & $25 \mathrm{Km} / \mathrm{h}$ & $\begin{array}{c}\text { Successful } \\
\text { data retrieval }\end{array}$ \\
\hline $\mathrm{C} 3$ & 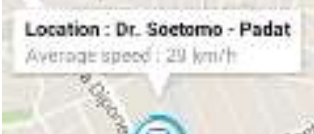 & $29 \mathrm{Km} / \mathrm{h}$ & $\begin{array}{c}\text { Successful } \\
\text { data retrieval }\end{array}$ \\
\hline
\end{tabular}

Table 9. Results of a data access information from the database at 12.00

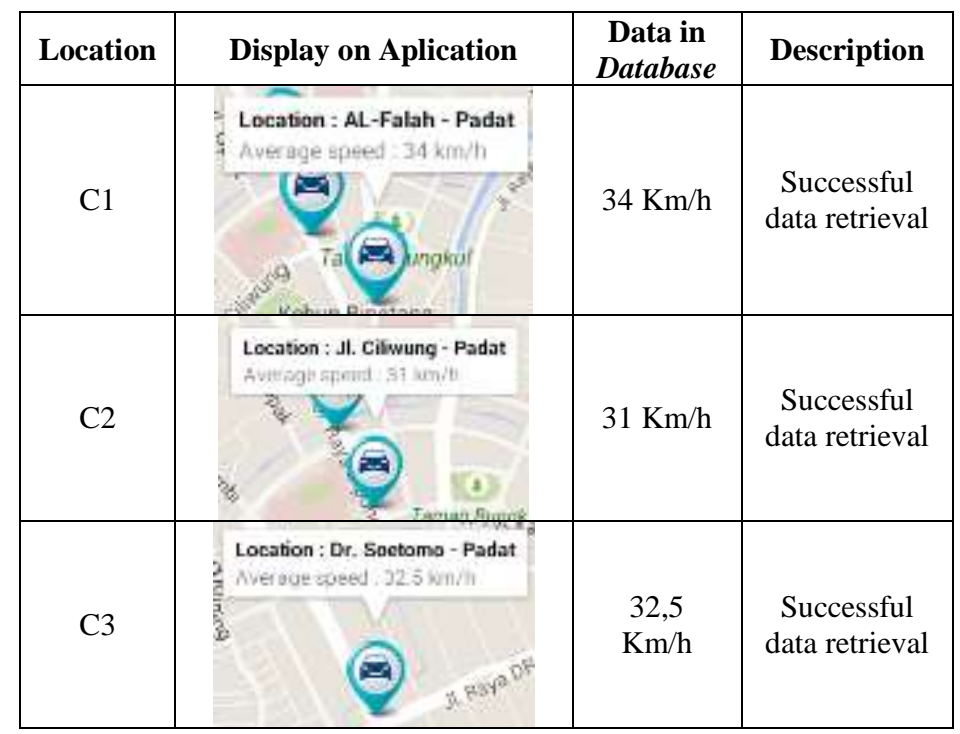

From Table 8 are the results of the comparison display of information on the application and the data from the database at 07.00 , it can be seen that the results of the data display information such as location, average speed and traffic indications on the 20 point locations with the data on the database. that applications can retrieve data from the database according to user access time. In Table 9 are the results of the comparison display of information on the application and the data from the database at 12.00 also shows the same result between the display of information to the database. 


\section{CONCLUTION}

Based on the results of the implementation of the manufacturing and testing of the data prediction system using Backpropagation Neural Network and the creation of applications for monitoring traffic, some conclusions can be drawn as follows:

1. These parameters in accordance with the Regulation of the Minister of Transportation No. KM 14 Year 2006 on Management and Traffic Engineering on the Road with indications: traffic conditions $\leq 25 \mathrm{Km} / \mathrm{h}$, solid conditions between $30 \mathrm{~km} / \mathrm{h} / \mathrm{d} 25 \mathrm{Km} / \mathrm{h}$ and substandard conditions $\geq 30 \mathrm{~km} / \mathrm{h}$.

2. From the results of prediction data, obtained Backpropagation best performance in scenario 2, namely at locations C20: Wapo, the Mean Square Error (MSE) of 8,91x10-24. The performance of the method Backpropagation seen from the MSE value, the smaller the MSE value, the better the performance and accuracy of data input.

3. Information on application "Traffic Monitor" has been able to show traffic congestion prediction information, the location with indication jammed, congested and smooth traffic with the description of the average speed of vehicles that pass through the area.

\section{ACKNOWLEDGEMENT}

Thanks to my colleague and member of microwave laboratory who have contributed to the success of this research. The author also wishes to thank to DP2M DIKTI that has funded research through grant competition

\section{REFERENCES}

[1] https://www.liputan6.com/bisnis/read/2465078/10-kota-dengan-lalu-lintas-terburuk-di-dunia (diakses 20 Juli 2018)

[2] https://urbandigital.id/aplikasi-lokasi-macet-jalan/(diakses pada tanggal 20 juli 2013)

[3] Mihaela Cardei, Iana Zankina, Ionut Cardei, dan Daniel Raviv, "Campus Assistant Application on an Android Platform", Department of Computer and Electrical Engineering and Computer Science Florida Atlantic University.

[4] sits.dishub.surabaya.go.id

[5] Peraturan Menteri Perhubungan Nomor: KM 14 Tahun 2006 Tentang Manajemen dan Rekayasa Lalu Lintas di Jalan, 2006

[6] Yi-Chung Hu dan Fang-Mei Tseng, "Applying Backpropagation Neural Networks to Bankruptcy Prediction", International Journal of Electronic Bussiness Management, Vol.3, No. 2, pp. 97-103, 2005

[7] Imam Shabri, Mike Yuliana dan Zaqiatul Darojah, "Prediksi Penggunaan Bandwidth PENS-ITS menggunakan Jaringan Syaraf Tiruan dengan Algoritma Backpropagation”, Jurnal Proyek Akhir Politeknik Elektronika Negeri Surabaya, 2012.

[8] Sri Redjeki, "Analisis Fungsi Aktivasi Sigmoid Algoritma Backpropagation Pada Prediksi Data", Jurnal Thesis Universitas Gadjah Mada, 2005.

[9] Didi Supriyadi, "Sistem Informasi Penyebaran Penyakit Demam Berdarah Menggunakan Metode Jaringan Syaraf Tiruan Backpropagation", Thesis Universitas Diponegoro Semarang, 2012.

[10] Daniel Soudry, Itay Hubara dan Ron Meir, "Expectation Backpropagation: Parameter-Free Training Of Multilayer Neural Networks With Continuous Or Discrete Weights”, Department of Statistics, Columbia University, 2014. 